\title{
A comparative study of secondary mathematics curricula of Turkey, Estonia, Canada, and Singapore
}

\author{
Fatma Serçe $^{1}$ and Filiz Acar ${ }^{2}$ \\ ${ }^{1}$ Düzce University, Education Faculty, Turkey (ORCID: 0000-0003-4803-2100) \\ ${ }^{2}$ Düzce University, Education Faculty, Turkey (ORCID: 0000-0002-0453-8508)
}

\begin{abstract}
This study aims to reveal the similarities and differences in the secondary mathematics curricula (SMC) of Turkey, Estonia, Canada, and Singapore during the 2018-2019 academic years by comparing them in terms of the curriculum components. In this context, the horizontal approach technique, one of the comparative education approaches, was used in the study. Secondary mathematics curricula of each country were subjected to content analysis using NVivo 10 qualitative analysis program. Curricula were examined in terms of general characteristics, objectives, content, learning-teaching process, assessment, and teacher's duties and responsibilities dimensions, and comparisons between countries were made. The results revealed that the majority of the learning outcomes in the SMC of Turkey and Estonia are in the knowing cognitive domain while applying is dominant in Canada and reasoning in Singapore SMCs. In addition, the SMC of Singapore provided the most detailed information regarding the assessment. Besides that, the SMC of Singapore was the curriculum that most comprehensively reflects the teacher's duties and responsibilities towards curriculum, teaching and learning process, and evaluation process.
\end{abstract}

Keywords: Comparative education; Secondary mathematics curriculum; Mathematics education

Article History: Submitted 30 November 2020; Revised 5 March 2021; Published online 17 March 2021

\section{Introduction}

Education is formed to meet the interests and needs of new generations, and it places a significant burden on organizations and individuals in this sense. This continuous state of transition in education has a direct impact on the curriculum and highlights the need to renew and update it regularly curriculum is an experience system that includes all activities related to the teaching of a course that is planned to be brought to the individual at school or outside of school (Demirel, 2019). It is important to have a well-designed curriculum. It will both guide the teacher in the process and make it easier for students to achieve their goals by eliminating redundant details. Many factors, such as the cultural structure of the countries, perception of education, expectations from future generations, and so on, play a role in the development of the curriculum. When looking at the curricula of different countries, it is clear that courses like mathematics, science, language education, and so on are the most basic in many of them. Because such courses serve as a

Address of Corresponding Author

Filiz Acar, PhD, Düzce University, Education Faculty, Department of Educational Sciences, 81620, Düzce, Turkey.

$\triangle$ filizac@hotmail.com

How to cite: Acar, F. (2021). A comparative study of secondary mathematics curricula of Turkey, Estonia, Canada, and Singapore. Journal of Pedagogical Research, 5(1), 216-242. http:/ /dx.doi.org/10.33902/JPR.2021167798 
cornerstone in the development of fundamental skills. Individuals' successes in these courses are also assessed in international exams. Although such courses are included in the curricula of countries, there may be differences in terms of content and structure. Countries, especially in recent periods, have changed their curricula due to the rapid advancement of technology. It has been understood that Mathematics education is more than four basic mathematical operations, formulas, and rules. By associating mathematics with daily life, its important functions, such as improving the individual's mathematical competencies and gaining higher-order thinking skills, come to the fore. The fact that mathematics education has an important place in the acquisition of these skills has caused many countries to give more importance to mathematics teaching and to organize their curricula accordingly (Usta, 2014). Because the needs of individuals have been reshaped with the changing world conditions; It has become important to train individuals who think analytically, perceive the problem as it is, and produce correct solutions to it (Ersoy, 2003).

Although countries adapt their education systems in response to these changes, they also undertake research into other educational systems. These studies are performed not only by governments but also by universities, various non-governmental organizations, and institutions. In particular, economically and socially superior countries are preferred in educational research (Çubukcu et al., 2016). International examinations are the most rigorous of these educational studies. Students are usually tested in basic areas such as reading skills, mathematics, and science on international exams such as the Programme for International Student Assessment (PISA), the Trends in International Mathematics and Science Study (TIMSS), and the Progress in International Reading Literacy Study (PIRLS). Furthermore, these tests not only provide knowledge about educational achievement but also about educational policy and sociological structure of countries, as well as the ability to forecast possible educational situations. In this way, countries can better analyze their educational systems and the educational situation in the international arena (Cambridge International, 2019; Güner et al., 2014). These exams are widely regarded as a secure means for countries to compare their educational accomplishments, both internally and externally. (Cambridge International, 2019; Ersoy, 2010; Güner et al., 2014).

This research aims to shed light on the current situation by comparing Turkey's secondary mathematics curriculum with that of countries that have performed well in international exams. The mathematics curriculum was chosen because countries place a greater emphasis on mathematics achievement than on other subjects (Işık et al., 2008; Seah \& Bishop, 2014), and there are few studies comparing secondary mathematics curriculum in Turkey. Considering the PISA and TIMSS mathematical results of these countries; In the PISA mathematics field, Singapore has gotten a high score in the last three exams it entered. Estonia has improved its score and grade on each exam, while Canada has attempted to maintain its high level of achievement. Turkey has improved its mathematics performance since the 2015 PISA, but it is still well below the Organisation for Economic Co-operation and Development [OECD] average. In the TIMSS mathematics field; Estonia does not participate in TIMSS and it is clear that Singapore has the highest score and rank among the participating countries. The success of Turkey's TIMSS exam and its ranking is not at the desired level, and it is still below average. Although Canada (Alberta) was not included in the province-based rankings, it has consistently produced positive results as a point (Mullis et al., 2012; Mullis et al., 2016; OECD, 2010, 2014, 2018, 2019; TIMMS 2019).

Secondary Mathematics Curricula (SMCs) in Singapore, Estonia, Canada, and Turkey are the fo cus of this study. The first three countries were chosen based on their outstanding performance in international exams. When looking through the literature, it is clear that there are few comparative education studies on secondary mathematics curriculum in Turkey. Examination of the secondary mathematics curricula of the countries showing success in international exams and comparison with the SMC of Turkey is important in terms of assessing the pros and cons of the secondary mathematics curriculum. This study is also expected to be useful in terms of providing inspiration to researchers working in this field. 


\subsection{The Aim}

This study compares the secondary mathematics curricula of Turkey, Estonia, Canada (Alberta), and Singapore in terms of curriculum components to reveal similarities and differences. For this purpose, the following questions have been sought.

When Turkish, Estonian, Canadian (Alberta), the Singapore Secondary Mathematics Curriculum are examined;

1. What are the similarities and differences in terms of general features?

2. What are the similarities and differences in terms of objectives?

3. What are the similarities and differences in terms of content?

4. What are the similarities and differences in terms of learning-teaching processes?

5. What are the similarities and differences in terms of evaluation?

6. What are the similarities and differences in terms of teacher's duties and responsibilities?

\section{Method}

A comparative educational research method was adopted into this study. Comparative research design is often used to compare two or more countries' cultural or national contexts. By examining curricula from various countries, this study hopes to uncover similarities and differences (Çubukçu et al., 2016; Ergün, 1985; Matthews \& Ross, 2010; Walliman, 2006). In this study, the horizontal approach technique was used, which is one of the comparative education approaches. In the horizontal approach, the parts that make up the education system of the countries are examined step by step, and the similarities and differences are revealed (Yıldırım \& Türkoğlu, 2018). The research also has a qualitative feature. Comparative research is suitable for both qualitative and quantitative methods (Walliman, 2006).

\subsection{Data Collection Tools}

An official published documentary was used as a data collection source in this study (Walliman, 2006). The secondary mathematics curricula for the 2018-2019 academic year in Turkey, Estonia, Canada (Alberta), and Singapore were accessed through the national education ministries' official websites. It was also confirmed that the curricula obtained through correspondence with the relevant ministries of the countries are current. When the curricula are examined, it is seen that they consist of various booklets and levels for different student levels. Here, firstly, the booklets were examined and the selection was made by looking at the content and scope. These curricula are given in Table 1.

Table 1

Secondary Mathematics Curricula of Turkey, Estonia, Canada (Alberta), and Singapore

\begin{tabular}{clll}
\hline \multicolumn{1}{c}{ Turkey } & \multicolumn{1}{c}{ Estonia } & \multicolumn{1}{c}{ Canada } & \multicolumn{1}{c}{ Singapore } \\
\hline Advanced math & Narrow mathematics / & 3-course sequence & $\mathrm{O} / \mathrm{N}(\mathrm{A}) / \mathrm{N}(\mathrm{T})$ \\
/ Basic math & Extensive mathematics & system $(-1,-2,-3)$ & level \\
\hline
\end{tabular}

When the curricula and their details are examined, the Turkish Secondary Mathematics Curriculum consists of a single booklet, while 9th and 10th grades use a joint curriculum, in 11th and 12th grades it is divided into two parts as basic-level and advanced level. While basic-level mathematics aims to overcome the possible problems that students who will not choose a mathematics-based department at higher education level, they may encounter in daily life, advanced mathematics is designed for students who will prefer a mathematics-based department at higher education (Ministry of National Education [MoNE], 2018). In this study, advanced mathematics, which is considered to be more comprehensive, will be investigated. The Estonian Secondary Education Mathematics Curriculum consists of a single booklet and handles mathematics as narrow and Extensive mathematics and lets the student choose the course (Republic of Estonia Ministry of Education and Research, 2014). The Secondary Mathematics Curriculum of Canada (Alberta) consists of a single booklet. In the SMC of Canada, course indexes 
are 10, 20, 30 and their levels are listed as -1,-2,-3 (Alberta Education, 2008). Since it is not appropriate to divide the course indexes here, all of them were examined. The Singapore Secondary Mathematics Curriculum consists of a single booklet and has five different mathematics curricula. These are $\mathrm{O}, \mathrm{N}(\mathrm{A}), \mathrm{N}(\mathrm{T})$ levels, and additional curricula of $\mathrm{O}, \mathrm{N}(\mathrm{A})$ levels. The O level curriculum is the most comprehensive, while the $N(A)$ and $N(T)$ levels are sub-curriculum of the O level. Since it is the most comprehensive curriculum here, this curriculum was included in the study (Ministry of Education Singapore, 2012).

\subsection{Data Analysis}

The data was analyzed using content analysis. Content analysis is the process of categorizing and quantifying the phenomenon or situation under investigation (Balc1, 2013). In this analysis process, each curriculum was transferred to the NVivo 10 program and coded according to the research questions. Explanations about the coding mode for each theme are given in Table 2.

Table 2

The Coding Structure of Secondary Mathematics Curricula According to Themes

Themes created based on Codes research questions

General Features Date of entry into force, the number of pages, values, competencies, e mathematical processes, and word frequency.

\begin{tabular}{ll}
\hline Objective & $\begin{array}{l}\text { Posner and Rudnitsky classification of goals, TIMSS Cognitive Domain } \\
\text { Classification of outcomes }\end{array}$ \\
\hline Content & Learning areas and topics \\
\hline $\begin{array}{l}\text { Learning-teaching } \\
\text { process }\end{array}$ & $\begin{array}{l}\text { Approaches; Methods and Techniques; Teaching principles; } \\
\text { Technology, Tools, and Materials }\end{array}$ \\
\hline Evaluation & Evaluation types and tools \\
\hline $\begin{array}{l}\text { Teacher's duties and } \\
\text { responsibilities }\end{array}$ & $\begin{array}{l}\text { The teacher's responsibilities duties towards the curriculum; duties and } \\
\text { responsibilities of teachers in the learning process; duties and } \\
\text { responsibilities of teachers in the evaluation process }\end{array}$ \\
\hline
\end{tabular}

In Table 2, explanations are given about the categories created in the coding process in line with the themes determined. Within the scope of general features, the formal features of the curriculum and the mathematical processes, the competencies, and values it contains are included. Examination of the objectives was handled in two categories as goals and learning-outcomes. The structure in Posner and Rudnitsky's (2006) classification was used in the classification of goals and the structure in the TIMSS cognitive domain classification was used in the classification of the learning-outcomes.

Posner and Rudnitsky grouped the learning objectives into two categories as skill and understanding. Understanding is about knowing principles, theories, facts, and generalizations. Skills include mental competencies such as problem-solving, reading, analysis, interpretation, application, and physical abilities, such as bicycling and ball throwing. The skill category is subdivided into psychomotor-perceptual skills, cognitive skills, and affective skills. Furthermore, the understanding category is subdivided into cognitions and affective understandings (Posner \& Rudnitsky's, 2006). According to Posner and Rudnitsky, while general purposes are classified, purposes that have more than one meaning are coded one by one for each meaning. For example, "formulates, demonstrates, and proofs mathematical hypotheses" is coded as three separate goal statements.

While examining the learning-outcomes, they were first classified according to cognitive, affective, and psychomotor domains. All learning-outcomes within the scope of cognitive skills were categorized using the TIMSS (2019) cognitive domain classification (Mullis \& Martin, 2017). The cognitive domain classification of TIMSS is divided into three main categories and is "knowing, applying and reasoning". Each domain is divided into sub-areas within itself (Figure 1). 
Figure 1

TIMMS cognitive domain

\begin{tabular}{|c|c|c|}
\hline Knowing & Applying & Reasoning \\
\hline $\begin{array}{l}\text { - recall } \\
\text { - recognize, } \\
\text { - classify / order } \\
\text { - compute } \\
\text { - retrieve/ read } \\
\text { - measure }\end{array}$ & $\begin{array}{l}\text { - determine } \\
\text { - represent / model } \\
\text { - implement }\end{array}$ & $\begin{array}{l}\text { - analyse, } \\
\text { - integrate / } \\
\text { synthesize } \\
\text { - evaluate } \\
\text { - draw conclusions } \\
\text { - generalize } \\
\text { - justify }\end{array}$ \\
\hline
\end{tabular}

During this classification process, all of the curricula' learning outcomes were thoroughly examined. The learning outcomes are not only categorized based on expression, but also by determining what the main goal of these outcomes is.

In examining the content theme, the learning areas and subjects included in the curriculum were presented in a table and compared according to countries. While analyzing the learningteaching process theme, the similarities and differences of the curricula were revealed in terms of the approaches, methods, and techniques, teaching principles, technology, and use of tools and materials. Assessment types and tools were analyzed in terms of issues to be considered in the evaluation theme. The teacher's responsibilities and duties in relation to the curriculum, the learning-teaching process, and the evaluation process were also discussed.

\subsection{Validity and Reliability}

The trustworthiness criterion of Guba and Lincoln (1982), which has been adopted by various circles, was used to ensure the validity and reliability of the research in this report. The researchers, who defined trustworthiness with the criteria of credibility, dependability, confirmability, and transferability, stated that these criteria were not independent of each other (Guba \& Licoln, 1985). To ensure trustworthiness, Turkey, Estonia, Canada, and Singapore, which are the subjects of research, were investigated in detail in advance, and information gathered about their education systems was included in the study. The translation of the curriculum was carried out meticulously, and the examples in the curriculum were studied in-depth to explain discrepancies in language between countries. Coding was conducted by Nvivo 10 qualitative analysis program. By doing an expert analysis, it was possible to improve the research's validity. The findings of a study conducted by another specialist with expertise in qualitative testing were reviewed step by step. The codes that were created based on expert guidance have been revised. 2011 (Cresswell \& Plano Clark). Furthermore, inter-coder reliability was used to improve the research's reliability (Miles \& Huberman, 2016). Two researchers worked on the coding independently of one another. According to Miles and Huberman's (2016) formula, the coding reliability coefficient among researchers is 87.39 percent. By renegotiating the inconvenient substances, the researchers were able to reach an agreement. The researchers attempted to assess the data objectively, avoiding personal biases and opinions. The data was recorded and saved to be analyzed later.

\section{Findings}

The themes obtained in line with the research questions and the sub-themes belonging to these themes are summarized in Figure 2. 
Figure 2

Themes and sub-themes in research

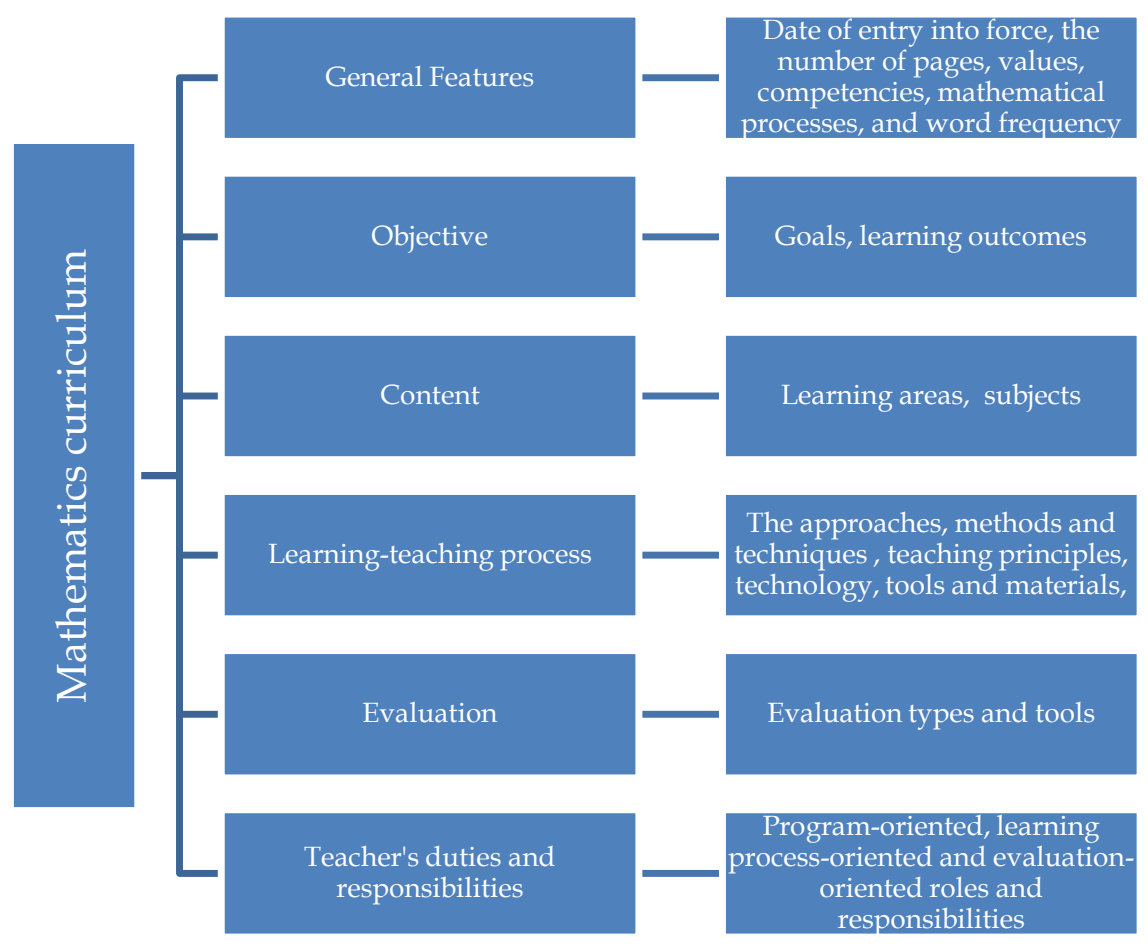

Findings were organized into six themes: general features, objective, content, learning-teaching process, evaluation, and teacher's duties and responsibilities. Tables related to the sub-themes in each theme are provided, with detailed explanations presented below in a comparative manner by country.

\subsection{Findings on the General Features of Turkish, Estonian, Canadian, and Singapore Curricula}

The Turkish SMC is a single 48-page booklet that went into effect in 2018. Turkish SMC consists of three parts. In the first part, the purpose, perspective, and assessment and evaluation approach of all curricula, in general, are mentioned. In the second part, the basic philosophy of the application of the curriculum, the points to be considered in teaching, the number, and the structure of the acquisitions are explained. In the last part, the structure of the mathematics curriculum is emphasized.

The Estonian SMC is a single booklet with 26 pages that has been in use with various updates since 2011. Estonian SMC consists of three parts. In the first part, general principles, competencies of mathematics, subject area titles, options for creating general competencies, options to integrate subjects with other subject areas, etc. are mentioned. In the second and third sections, narrow, extensive, and optional mathematics topics, aims of education, explanation of the subjects, and learning outcomes are given.

SMC in Canada (Alberta) is a single booklet with 46 pages that has been used with various updates since 2008. Canadian SMC, the purpose of curriculum, the importance of learning mathematics, the approach based on cultures, the importance of the emotional field, and the student goals, among other things, are mentioned.

The Singapore SMC is a single booklet with 69 pages. It's been in use since 2012, with regular updates. The curriculum states that the updates made are mostly aimed at learning-teaching processes, and that these are reviewed according to the needs of the time, and that there are limited changes in the content. The Singapore SMC consists of five parts. The first part consists of goals and lesson plan. The second part focuses on the mathematical framework and the 
importance of problem-solving. The third part talks about teaching, learning, and experience. The fourth and fifth sections discuss objectives, lesson plans, process steps, content, and learning experiences for level $\mathrm{O}$ and $\mathrm{N}(\mathrm{A})$ mathematics, respectively.

In this section, the general structure of Turkish, Estonian, Canadian, and Singaporean mathematics curricula was examined in four sections: values, competencies, mathematical processes, and the most frequently used words. Table 3 shows the concept of values in Turkish, Estonian, and Canadian mathematics curricula. There is no concept in Singapore that is referred to as values.

Table 3

Concepts About Values in Secondary Mathematics Curricula

\begin{tabular}{llll}
\hline Curriculum & Turkey & Estonia & Canada \\
\hline & Justice & Decency & Conscious decision making \\
& Friendship & Diligence, Systematic & Perseverance \\
& Honesty & Approach, Persistence, & \\
Values & Respect & Steadiness Integrity & \\
& Love & Tolerant Attitude & \\
& Responsibility & & \\
& Patriotism & & \\
& Helpfulness & & \\
& & & \\
\hline
\end{tabular}

When the values provided in the Turkish mathematics curriculum are analyzed; it is observed that main values include justice, friendship, honesty, self-control, patience, respect, love, responsibility, patriotism, helpfulness concepts are given under the title Values. These are general values that are not specific to mathematics education. Under the heading of Values and Morality in the Estonian mathematics curriculum, general and mathematics-specific values such as "decency, diligence, systematic approach, persistence, steadiness and integrity, tolerant attitude" are listed together. While the Canadian mathematics curriculum does not directly state values, it can be said that it partially emphasizes values education with this expression "Making informed decisions as contributors to society..... making them willing to persevere....". Singapore's mathematics curriculum does not include any information on values.

In Table 4, statements of competence in the mathematics curricula of the countries are given

Table 4

Competence Statements in Secondary Mathematics Curriculums

\begin{tabular}{lll}
\hline Curriculum & Turkey & Estonia \\
\hline & Communication in the mother tongue & Communication competence \\
& Communication in a foreign language & Learning to learn competence \\
& Learning to learn & Social and Citizenship Competence \\
Social and Citizenship competencies & Entrepreneurial competence \\
& Taking initiative and & Cultural and value competence \\
entrepreneurship & Natural sciences and technology \\
Mathematical competence & competence \\
& Basic competencies in science and & Self-awareness competence \\
technology & \\
Digital competence & \\
& Cultural awareness and expression & \\
\hline
\end{tabular}

While Turkish and Estonian SMCs include competencies, Canadian and Singapore SMC do not have any expressions. Turkish SMC states competencies in eight titles while Estonian states them in seven. Competencies such as communication, learning to learn, social and citizenship, entrepreneurship, values, and cultural competence are expressed in common in Turkish and Estonian SMC. Mathematical competence, basic competencies in science and technology, and 
digital competencies are available only in the Turkish SMC. Natural sciences and technology competencies and self-awareness competence are only included in Estonian SMC. The Singapore SMC mentions developing 21st-century skills but does not define exactly what those skills are. In Turkish SMC the aim of the education system is defined as to gain individuals knowledge, skills, and behaviors besides national values and competencies (the actions form of the national values) by emphasizing the importance of competency. On the other hand, Estonian SMC defined the competencies by associating them with the field of mathematics. The important point to note here is that, while Estonian and Turkish mathematics curricula share some common competencies, they express different things. For example, the Turkish SMC explains social and citizenship competence to enable individuals to effectively and constructively participate in a differentiated society and work environment. In Estonian SMC, on the other hand, It is aimed to use problem-solving related to the content, to participate in a variety of paired and group work assignments, and to develop cooperation and mutual aid skills in order to build responsibility towards society and other citizens.

It was discovered that the curricula included explanations of mathematical processes. Table 5 shows Canada's and Singapore's mathematical process explanations. There is no explanation for Turkey and Estonia.

Table 5

Mathematical Processes in Secondary Mathematics Curriculums

\begin{tabular}{lll}
\hline Curriculum & Canada & Singapore \\
\hline Mathematical Processes & Reasoning & Reasoning \\
& Communication & Communication and \\
& Connections & Connections \\
& Mental Mathematics & Applications and Modelling \\
and Estimation & Thinking Skills and Heuristics \\
& Problem-Solving & Methods \\
& Technology & \\
& Visualization & \\
\end{tabular}

While Singapore SMC defines mathematical processes as the process skills involved in acquiring and applying mathematical knowledge, SMC in Canada indicates the critical aspects of learning, doing, and understanding mathematics and states that students should be regularly encountered with these processes to achieve the goals of mathematics education. According to Table 5, common mathematical processes in the Canadian and Singapore curricula include reasoning, communication, and connections. Both curricula describe these processes in similar terms. It is defined as the ability to reason, analyze mathematical events, and think logically. The most important feature of reasoning is that it is a thinking skill that can be developed. Communication is the clear expression of mathematics with its own formal and symbolic language. Students who develop communication skills will also improve their mathematical understanding. Connections refer to the ability to connect and see between mathematical ideas, between mathematics and other subjects, and between mathematics and the real world. Making connections with students' experiences and associating are important in developing mathematical understanding.

The mathematical processes that were only included in the Canadian SMC can be summarized as follows; Mental mathematics is a combination of cognitive strategies that foster flexible thinking and number perception. It is stated that by using mental mathematics, the student will create confidence in mathematics, tend to use different strategies in problem-solving, and develop flexible thinking. While predicting provides mathematical judgments, it is regarded as very important in terms of requiring different strategies to calculate the result approximately, and teaching how the student should use strategies. The curriculum, which states that visualization involves thinking about pictures and images as well as the ability to perceive, transform, and 
recreate different aspects of the visual-spatial world, also states that using visualization in mathematical studies allows students to better understand and connect mathematical concepts. One of the foundations and basic processes of mathematics is problem-solving. Mathematics at all levels emphasizes problem-solving learning, and when students solve problems in meaningful contexts, they gain a thorough understanding of mathematical concepts and procedures. Hence, problem-solving is a powerful teaching tool that encourages creative and innovative solutions. Technology can be used effectively to contribute and support the learning of a wide variety of mathematical results. Technology enables students to discover and create patterns, examine relationships, test assumptions, and solve problems. The use of technology should not replace mathematical understanding. Instead, technology should be used as one of several approaches and tools to build mathematical understanding. Although problem-solving and technology are not included in mathematical processes in Singapore SMC, problem-solving is described as the focus of the mathematical framework created by Singapore SMC, and the curriculum has been designed accordingly. Technology, on the other hand, is given as a teaching principle of using ICT in Singapore SMC and is not mentioned in mathematical processes.

The curriculum, which states that the application and modeling specified in Singapore SMC is a process of creating and developing a mathematical model to represent and solve real-world problems, states that by improving mathematical competencies, basic concepts and methods can be more easily understood. This can be accomplished by providing the student with a variety of open-ended and life-related problem-solving opportunities. Thinking skills and heuristic methods consist of a combination of various thinking skills and intuition. These are essential for solving mathematical problems.

The vocabularies used in Secondary Mathematics Curricula in Turkey, Estonia, Singapore, and Canada were examined in terms of general characteristics. In the analyses, the most common concepts used in each country's curriculum were examined, and the five most frequently mentioned concepts were tabulated. Table 6 shows the total number of words in the curriculum as well as the most commonly used concepts.

Table 6

Most Commonly Used Concepts in Secondary Mathematics Curricula

\begin{tabular}{llllll}
\hline $\begin{array}{l}\text { Countries } \\
\text { (Total } \\
\text { vocabularies) }\end{array}$ & 1stword & 2nd word & 3rd word & 4th word & 5th word \\
\hline $\begin{array}{l}\text { Turkey } \\
(6685)\end{array}$ & $\begin{array}{l}\text { Function } \\
(155)\end{array}$ & $\begin{array}{l}\text { Number } \\
(86)\end{array}$ & $\begin{array}{l}\text { Problem } \\
(85)\end{array}$ & $\begin{array}{l}\text { Concept } \\
(75)\end{array}$ & $\begin{array}{l}\text { Set } \\
(75)\end{array}$ \\
\hline Estonia & Function & Mathematic & $\begin{array}{l}\text { Problem } \\
(59)\end{array}$ & $\begin{array}{l}\text { Learning } \\
(53)\end{array}$ & $\begin{array}{l}\text { Equation } \\
(52)\end{array}$ \\
\hline $\begin{array}{l}\text { Canada } \\
(5131)\end{array}$ & Mathematic & Student & Problem & Outcomes & Demonstrate an \\
& $(181)$ & $(161)$ & $(130)$ & $(131)$ & $\begin{array}{l}\text { understanding } \\
(94)\end{array}$ \\
\hline $\begin{array}{l}\text { Singapore } \\
(6408)\end{array}$ & Mathematic & Learning & Student & Problem & Syllabus \\
& $(307)$ & $(186)$ & $(167)$ & $(93)$ & $(72)$ \\
\hline
\end{tabular}

According to Table 6, Turkish SMC (6685) has the most words, while Estonian SMC has the fewest words (3809). Singapore has 6408 words and Canadian has 5311. In all four curricula, the word "problem" is the most frequently used common concept.

Among the five most commonly used concepts in Turkish SMC are "function," "number," "problem," "concept," and "set." Each learning outcome in the curriculum has its own subexplanations. These concepts are commonly found in sub-explanations. As the curriculum emphasizes concept teaching, the word "concept" appears frequently. The concept of mathematics is prevalent in other countries' curricula, but not in Turkish SMC. It's possible that this is due to the lack of discipline-specific explanations in the curriculum's introduction, instead opting for more 
general statements. There are joint statements in the introductions of different teaching curricula at various levels in Turkey.

The words "function", "mathematics", "problem", "learning", and "equation" are among the most frequently mentioned concepts in Estonian SMC. In the curriculum, the terms "function", and "equation" are used frequently as they are included in both learning outcomes and the content of the curriculum. The word "mathematic" is frequently used as the expressions in the curriculum are associated with the mathematics discipline, while the word "learning" is important in terms of showing the emphasis on the learning-teaching processes of the curriculum. Also, it is seen that the word "problem" is also used frequently, as the Estonian SMC mentions the importance of problem-solving in various parts of the curriculum.

The terms "mathematics," "student," "problem," "outcomes," and "demonstrate understanding" are frequently used in Canadian SMC. The frequent use of the word "student" is consistent with the curriculum's goal of student relativity. In comparison to other curricula, Canadian SMC includes the most problem-solving activities. It is also noteworthy that, different from other curricula, "demonstrate understanding" and "learning outcomes" take place here. As an expression included in learning outcomes, develop understanding' is about the student's structuring of knowledge and demonstrating it. Many learning outcomes are frequently used in the curriculum because they are expressed in this way.

Finally, the Singapore curriculum frequently employs the terms "mathematics," "learning," "student," "problem," and "syllabus." The importance of learning-teaching processes rather than content is expressed in the curriculum, and teaching is emphasized. It also prioritizes problemsolving in the curriculum, emphasizing student-centered education, and expressing this in various ways. This aspect of the curriculum can be said to be consistent with frequently used words.

\subsection{Findings on the Goals and Learning Outcomes of Turkish, Estonian, Canadian, and Singapore Curriculums}

\subsubsection{Classification of goals}

The structure developed by Posner and Rudnitsky (2006) for classifying goals was used in the classification of curriculum goals. When it comes to curriculum goals, Turkey has nine, Estonia has 41, Canada has 15, and Singapore has nine. Figure 3 shows the distribution of goals according to the structure proposed by Posner and Rudnitsky.

Figure 3

Frequency of the Curriculum Goals According to Posner and Rudnitsky's Classification

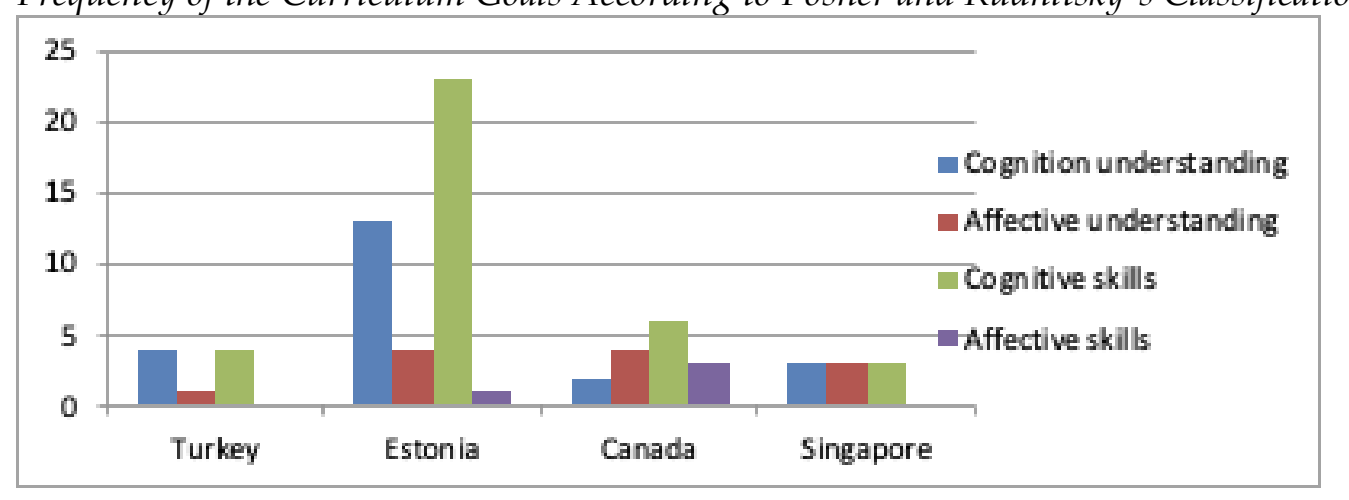

Turkish and Singaporean SMCs have the least amount goals, while Estonian SMCs have the most, as shown in Figure 3. Estonian and Canadian SMCs include affective skills in goals whereas there are not any goals related to affective skills in Turkish and Singapore SMCs. No generalpurpose was found that could be included in the scope of psychomotor skills in the general objectives of the curricula examined.

It is understood that Turkish SMC, giving equal place to learn the knowledge and practices, gives priority to the cognitive domain. The goals of the cognitive domain are to identify the 
historical development process of mathematics, identify scientists who have contributed to its development and their studies, improve their problem-solving skills by looking at problems from different angles, develop a perspective on whether a problem they encounter in life is a problem for them and reach a certain level of knowledge. With the expression "appraises learning mathematics and mathematics" the goal of the affective domain is stated.

The Estonian SMC has more goals than other countries and focuses primarily on cognitive skills. The majority of Estonian SMC's goals are expressed in a way that requires students to organize and use information. For example; "Understands and analyses mathematical texts and presents mathematical thinking structures in oral and written form, uses mathematical methods in other disciplines and areas of life, presents a problem in a mathematical language, and interprets and critically evaluates mathematical models". In addition, the curriculum also includes objectives related to the affective domain such as "apprises mathematics, understands the social, cultural and personal importance of mathematics".

As shown in Figure 3, Canadian SMC is primarily concerned with cognitive skills, but it also places a valuation on affective abilities. In addition to the goals of 'problem-solving, mathematical reasoning,' which express the student's internalization of knowledge and practical demonstration of it, the Canadian SMC includes affective goals that indicate individuals' understanding and appreciation of the role of mathematics in society and developing a positive attitude toward mathematics.

On the other hand, the goals of Singapore SMC are mainly included in the cognitive domain. Singapore SMC gives goals related to the application of knowledge in the cognitive domain as developing problem-solving, thinking, reasoning, communication, application, and metacognitive skills with a mathematical approach, linking ideas between mathematics applications and mathematics and other subjects through mathematical applications. It can be seen that it includes goals in affective domain, such as developing positive attitudes and confidence towards mathematics, knowing the value of making conscious decisions in real life.

\subsubsection{Classification of learning-outcomes}

In the analyzed mathematics curricula, the learning outcomes were coded and classified, and it was discovered that all learning outcomes were in cognitive structure, and with no affective or psychomotor learning outcomes. The reason for this is that secondary school mathematics lessons have a cognitive structure due to their nature and education is made through more abstract concepts and that it causes the affective and psychomotor areas to weaken.

Because all of the acquired learning outcomes are in cognitive structure, the TIMSS cognitive domain classification was used. TIMSS categorizes cognitive domains into three major categories: knowing, applying, and reasoning. According to the cognitive areas, the scope of the applied TIMSS mathematics achievement test is distributed as follows: 35\% knowing, 40\% applying, and 25\% reasoning (TIMSS \& PIRLS, 2019). Figure 4 depicts the frequency distribution of all learning outcomes based on their distribution status within the curriculum.

According to Figure 4, Turkish and Estonian SMCs have common features. While the distribution of the learning-outcomes is predominant in the area of knowing, there are fewer outcomes in the area of reasoning, which includes the processes of reasoning. It is seen that the learning outcomes of Turkish and Estonian SMCs are not distributed in a balanced way and that the learning outcomes related to the development of high-level reasoning skills appear to be inadequate. However, since the Estonian SMC is a framework curriculum, it should be known that the teaching process contains mainly problem-solving, although it seems to give outcomes for the area of knowing. 
Figure 4

Frequency Distribution of Learning-outcomes According to TIMSS Cognitive Domain Classification

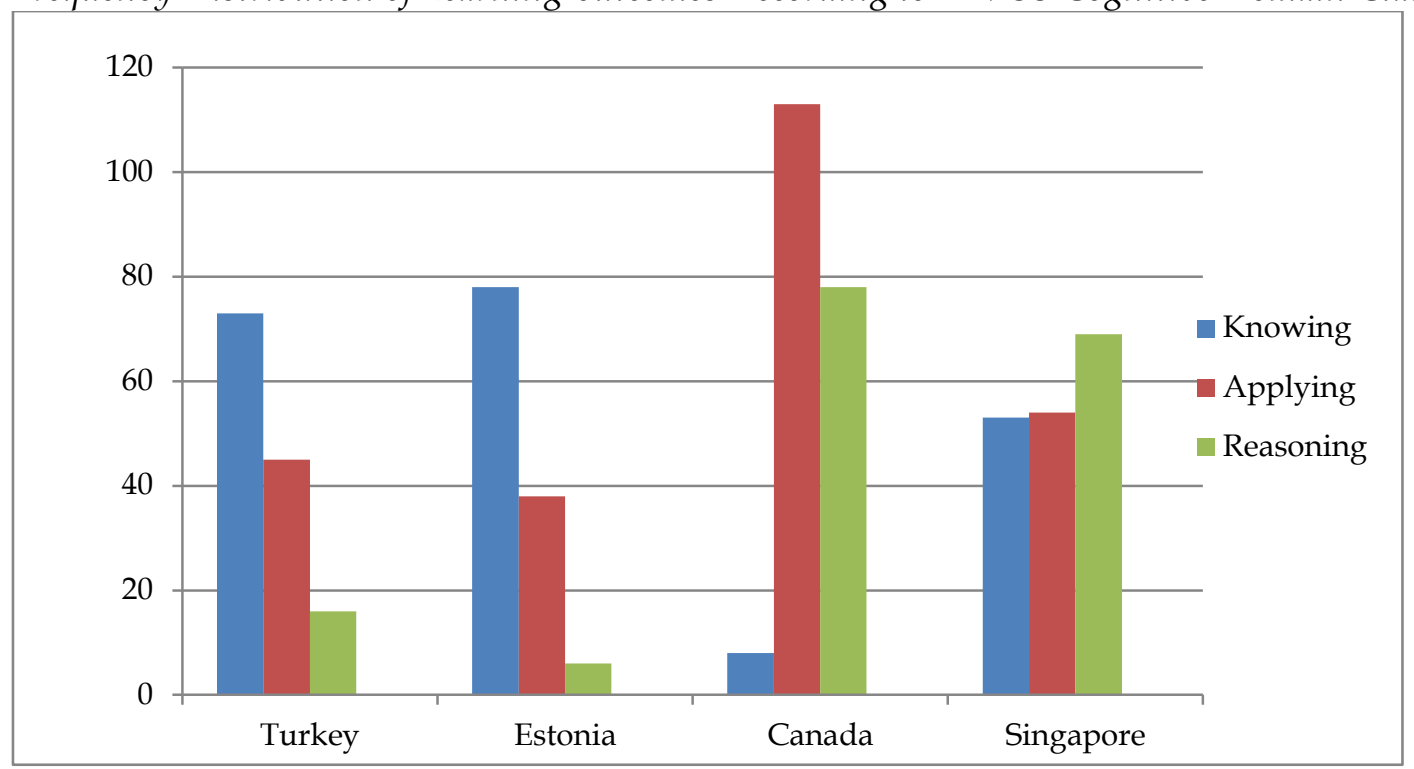

When the learning-outcomes distribution of the Canadian curriculum is considered, the area of applying is the highest, followed by the area of reasoning with a small difference. However, it is clear that the learning outcomes in the area of knowing are quite low. When the distribution of learning outcomes is examined, it is discovered that more high-level outcomes are attempted to be achieved.

The Singapore curriculum, on the other hand, has a similar distribution to the TIMMS classification but emphasizes reasoning a little more. According to the Singapore curriculum, each student's mathematical ability varies, and the curriculum aims to teach mathematics at the highest level that each student is capable of achieving. Looking at the proportional distribution of learning outcomes, it is possible to conclude that there is consistency between these goals and the distribution of learning outcomes.

As a result, Turkish and Estonian curricula place an emphasis on cognitive processes like remembering, identifying, classifying, computing, and so on, whereas the Canadian curricula place an emphasis on applying processes like determining strategies, modeling, and implementing. It also emphasizes reasoning skills like analyzing, synthesizing, evaluating, and justifying. The Singapore curriculum, on the other hand, takes a balanced approach to allknowing, applying, and reasoning processes.

\subsection{Findings on the Content of Turkish, Estonian, Canadian, and Singapore Curricula}

Considering the content of mathematics curricula in different countries, the subjects in Turkey and Singapore were observed to be clustered under learning areas. SMC learning areas were not specified in Canada as well as Estonia, but subject headings were used instead. Subject distribution was made taking into account learning areas in Turkish SMC while analyzing the content to make comparisons. In the learning area of "number and algebra," Table 7 displayed the content distribution of the countries' curricula. 
Table 7

Content Distributions According to the "Number and Algebra" Learning Area

\begin{tabular}{|c|c|c|c|}
\hline Turkey & Estonia & Canada & Singapore \\
\hline Sets & - & - & $\begin{array}{l}\text { Set language and } \\
\text { notation }\end{array}$ \\
\hline $\begin{array}{l}\text { Equations and } \\
\text { Inequalities }\end{array}$ & $\begin{array}{l}\text { Equations and equation } \\
\text { systems of equations }\end{array}$ & Algebra and Number & $\begin{array}{l}\text { Equations and } \\
\text { inequalities }\end{array}$ \\
\hline Quadratic Equations & $\begin{array}{l}\text { Inequalities } \\
\text { Expressions } \\
\text { Numerical quantities }\end{array}$ & & $\begin{array}{l}\text { Number and their } \\
\text { operations } \\
\text { Ratio and proportion } \\
\text { Percentage } \\
\text { Rate and speed } \\
\text { Algebraic expressions } \\
\text { and formulae }\end{array}$ \\
\hline $\begin{array}{l}\text { Functions and } \\
\text { Applications in } \\
\text { Functions }\end{array}$ & Functions & \multirow{2}{*}{$\begin{array}{l}\text { Relations and } \\
\text { Functions }\end{array}$} & Functions and graphs \\
\hline $\begin{array}{l}\text { Exponential and } \\
\text { Logarithmic Functions }\end{array}$ & $\begin{array}{l}\text { Exponential and } \\
\text { Logarithmic Function }\end{array}$ & & - \\
\hline Sequences & Numerical Sequences & - & - \\
\hline Derivative & $\begin{array}{l}\text { Applications of } \\
\text { Derivatives } \\
\text { Limit and Derivative of } \\
\text { Function }\end{array}$ & - & - \\
\hline $\begin{array}{l}\text { Integral } \\
\text { Polynomials }\end{array}$ & Integral & - & - \\
\hline
\end{tabular}

In the area of Numbers and Algebra, Estonian and Turkish curricula include similar subjects; however, limit, derivative, and integral, which are advanced subjects, are not included in Canadian and Singapore SMCs. Table 8 shows the distribution of subjects by geometry learning area.

Table 8

Content Distributions According to the "Geometry" Learning Area

\begin{tabular}{llll}
\hline Turkey & Estonia & Canada & Singapore \\
\hline Circle & - & Geometry & Circle properties \\
\cline { 1 - 1 } $\begin{array}{l}\text { Triangles } \\
\begin{array}{l}\text { Quadrilaterals } \\
\text { Polygons }\end{array}\end{array}$ & - & & $\begin{array}{l}\text { Angles, triangles, and } \\
\text { polygons }\end{array}$ \\
\hline Stereometry & $\begin{array}{l}\text { Line and plane in space } \\
\text { Stereometry }\end{array}$ & - & - \\
\hline Trigonometry & $\begin{array}{l}\text { Trigonometry Part 1 } \\
\text { Trigonometry Part 2 } \\
\text { Trigonometric functions }\end{array}$ & Trigonometry & $\begin{array}{l}\text { Pythagoras' theorem } \\
\text { and trigonometry }\end{array}$ \\
\hline Analytical geometry & Equation of the line & - & Coordinate geometry \\
\hline
\end{tabular}

Turkish, Canadian, and Singapore SMCs are closer to each other in the Geometry Learning area while Estonian SMC gives place to such basic geometry terms as angle, triangle, and circle under different topics. However, Estonia has learning outcomes related to these subjects. Canada, on the other hand, gives learning outcomes on these subjects under the title of geometry. The distribution of topics according to the "data counting and probability" learning area is shown in Table 9. 
Table 9

Content Distributions According to the "Data Counting, and Probability" Learning Area

\begin{tabular}{llll}
\hline Turkey & Estonia & Canada & Singapore \\
\hline Data, counting, and & Probability and & Statistics & Data analysis \\
probability & statistics & Permutation, & Probability \\
& & Combination and & \\
& & Binomial Theorem & \\
\hline
\end{tabular}

In terms of content, Turkey's curriculum is more intense than that of other countries, as shown in Table 9. While Estonian and Canadian SMCs include statistics subjects in the areas of data, counting, and probability, Turkish and Singaporean SMCs do not. Some of the subjects in the curricula of these countries do not match Turkey's curriculum and remain uncovered. These subject titles are presented in Table 10.

Table 10

Distribution of Subjects that are not Common Among Countries

\begin{tabular}{lll}
\hline Estonia & Canada & Singapore \\
\hline Vector on plane & Measurement & Problems in real-world contexts \\
Applications of mathematics and & Mathematics Research Project & Measuration \\
examination of real processes & & Matrices \\
& & Vectors in two dimensions \\
\hline
\end{tabular}

As can be seen in Table 10, the subjects that integrate math and life, such as applications and measuring, have no counterparts in the Turkish curriculum.

\subsection{Findings on Learning-Teaching Processes of Turkish, Estonian, Canadian, and Singapore Curriculum}

Learning-teaching processes are quite extensive. In this section, the approaches, methods, and techniques used in the teaching process; teaching principles; by using technology, tools, and materials, the similarities and differences of the curricula were tried to be revealed.

\subsubsection{Approaches used in the teaching process}

By examining the mathematics curricula of the countries, the approaches that are implicitly or explicitly stated in the curricula are analyzed and given in Table 11.

Table 11

Approaches Used in the Teaching Process

\begin{tabular}{|c|c|c|c|c|}
\hline & Turkey & Estonia & Canada & Singapore \\
\hline $\begin{array}{l}\text { Manipulative, visual, and various } \\
\text { pedagogical approaches }\end{array}$ & - & - & $\checkmark$ & - \\
\hline Direct instruction & - & - & - & $\checkmark$ \\
\hline Teaching through guided inquiry & - & - & - & $\checkmark$ \\
\hline Harmonic approach & $\checkmark$ & - & - & - \\
\hline Cooperative teaching & $\checkmark$ & $\checkmark$ & - & $\checkmark$ \\
\hline Individualized approach & $\checkmark$ & $\checkmark$ & $\checkmark$ & $\checkmark$ \\
\hline Activity-based teaching & - & $\checkmark$ & - & $\checkmark$ \\
\hline Reflective teaching & - & - & - & $\checkmark$ \\
\hline Interdisciplinary teaching & - & $\checkmark$ & - & - \\
\hline Problem-solving approach & $\checkmark$ & $\checkmark$ & $\checkmark$ & $\checkmark$ \\
\hline Project-based approach & $\checkmark$ & $\checkmark$ & $\checkmark$ & $\checkmark$ \\
\hline
\end{tabular}


When Table 11 is consdiered, it is clearly seen that the problem-solving approach and the project-based approach are used in all of the curricula. Only Canadian SMC has manipulative, visual, and various pedagogical approaches; Turkish SMC has a harmonic approach, Singapore SMC has reflective teaching, and Estonian SMC has an interdisciplinary approach

When the curricula are examined, countries related to teaching approaches stated the following: Turkish SMC expresses that it considers multi-faceted human development by adopting holistic approach in order to get a holistic development. Regarding the individualized approach states that the curricula are structured by considering the sensitivities of individual differences. With the project-based learning approach, students are expected to fulfill the tasks in the scientific study steps. Although there are no expressions under the problem-solving approach, it is seen that the curriculum emphasizes problem-solving in its goals, learning-outcomes, and explanations about learning-outcomes.

The Estonian SMC, by supporting an individualized approach, emphasizes the need to use assignments of varying quality and difficulty and to increase students' motivation to study. Expressing the collaboration of teachers with students for cooperative learning, the curriculum recommends the development of cooperation and mutual assistance skills through a variety of paired and group work assignments. The curriculum, which allocates a wide space for interdisciplinary teaching, aims to integrate mathematics teaching with these areas by pointing to different areas of use of mathematics and to help students gain various skills and sensitivities. Although problem-solving and project-based learning is not directly stated, the competencies defined are associated with problem-solving, and teaching through project-based learning is encouraged.

Canadian SMC, by recommending the use of manipulative, visual, and various pedagogical approaches, expresses the need to address the diversity of students' learning styles and their development stages and emphasizes the meaningful learning of students. Although the curriculum does not directly mention the Individualized approach, it states that the key factor in the development of mathematical literacy of students who come to school with a variety of knowledge, life experiences, expectations, and backgrounds is to establish a connection with these backgrounds, experiences, goals, and aspirations. It can be said that the curriculum adopts an individualized approach by showing that the teaching is done by taking the interests and needs of the individual into consideration. Stating that the problem-solving approach is the main focus, the curriculum emphasizes the importance of students developing their strategies by listening, discussing, and experimenting with different problem-solving strategies.

Unlike other curricula, the Singapore SMC goes into great detail about the learning-teaching process. The curriculum explains the approaches used in the association section under the title of stages of learning in detail. The following are a few examples of these approaches: Learning by doing is the goal of activity-based teaching. Instead of providing answers, teacher-guided inquiry encourages students to research, discover, and find answers on their own. Direct instruction allows students to concentrate on their learning objectives while teachers make connections, ask questions, highlight key concepts, and consider role models. Defining problem-solving as the essence, the curriculum has prepared a mathematical framework for this and it has been arranged accordingly.

\subsubsection{Methods and techniques used in the teaching process}

The methods and techniques stated implicitly or explicitly in the curricula by examining the mathematics curricula of the countries are given in Table 12. 
Table 12

Methods and Techniques Used in the Teaching Process

\begin{tabular}{lcccc}
\hline & Turkey & Estonia & Canada & Singapore \\
\hline Roleplay & - & $\checkmark$ & - & - \\
\hline Debate & - & $\checkmark$ & - & - \\
\hline Student research & - & $\checkmark$ & $\checkmark$ & $\checkmark$ \\
\hline Verbal lecture & - & - & $\checkmark$ & - \\
\hline Project implementations & $\checkmark$ & $\checkmark$ & $\checkmark$ & $\checkmark$ \\
\hline $\begin{array}{l}\text { The compilation (for portfolios and research } \\
\text { articles) }\end{array}$ & - & $\checkmark$ & - & - \\
\hline Study assignments & - & $\checkmark$ & - & - \\
\hline Role model thinking & - & - & - & $\checkmark$ \\
\hline Note-taking & - & - & - & $\checkmark$ \\
\hline Anecdote & $\checkmark$ & - & - & - \\
\hline Demonstration & $\checkmark$ & $\checkmark$ & $\checkmark$ & $\checkmark$ \\
\hline Observation & $\checkmark$ & $\checkmark$ & $\checkmark$ & $\checkmark$ \\
\hline Prediction & - & - & $\checkmark$ & $\checkmark$ \\
\hline Asking questions & $\checkmark$ & - & $\checkmark$ & $\checkmark$ \\
\hline Discussion & - & $\checkmark$ & $\checkmark$ & $\checkmark$ \\
\hline Game & - & - & $\checkmark$ & $\checkmark$ \\
\hline Models & $\checkmark$ & $\checkmark$ & $\checkmark$ & $\checkmark$ \\
\hline Applications & $\checkmark$ & $\checkmark$ & $\checkmark$ & $\checkmark$ \\
\hline Simulation & - & - & $\checkmark$ & - \\
\hline
\end{tabular}

Project implementations, demonstration, observation, models, and practices are all included in all curricula, according to Table 12. Roleplaying, debate, verbal expression, portfolio and compilation of research articles, study assignments, role model thinking, anecdote, simulation are methods and techniques that are not common in each country's curriculum.

The statements of curricula that are seen as important on methods and techniques as follows: Turkish SMC specifies that anecdotes should be used according to student level. Estonian SMC mentions the use of various active learning approaches in the learning process and states that appropriate methods and techniques can be used. Canadian SMC states that the methods, techniques, and experiences used in the learning-teaching process are crucial to learning and understanding and explains some of them in detail. What draws attention here is that the prediction technique is important in making mathematical judgments and developing appropriate strategies to cope with situations in daily life. Also, in the teaching process structured like games, it has been stated in the curriculum that students learn by experience and structure mathematical concepts better. Singapore SMC gives detailed information about applications and models; It states that teaching with these methods and techniques will enable students to connect the mathematics they have learned to the real world, to understand basic mathematical concepts and methods, and to improve their mathematical competence.

\subsubsection{Teaching principles used in the teaching process}

The texts in the curricula relating to learning-teaching processes were examined, and inferences were drawn based on implicit or explicit statements about teaching principles. The principles determined in the curricula are listed and that in which curricula these principles are given in Table 13. 
Table 13

Teaching principles used in the teaching process

\begin{tabular}{lcccc}
\hline & Turkey & Estonia & Canada & Singapore \\
\hline Openness & - & - & - & $\checkmark$ \\
\hline Integrity & $\checkmark$ & $\checkmark$ & - & - \\
\hline Simple to complex & - & - & $\checkmark$ & $\checkmark$ \\
\hline Up-to-dateness & $\checkmark$ & $\checkmark$ & - & $\checkmark$ \\
\hline Securing knowledge and skills & $\checkmark$ & $\checkmark$ & $\checkmark$ & - \\
\hline Goal-oriented & $\checkmark$ & $\checkmark$ & $\checkmark$ & $\checkmark$ \\
\hline Proximity (The close away) & - & - & $\checkmark$ & $\checkmark$ \\
\hline From concrete to abstract & $\checkmark$ & - & $\checkmark$ & $\checkmark$ \\
\hline $\begin{array}{l}\text { Active participation (learning by doing and } \\
\text { experiencing) }\end{array}$ & $\checkmark$ & $\checkmark$ & $\checkmark$ & $\checkmark$ \\
\hline Known to unknown & $\checkmark$ & - & $\checkmark$ & $\checkmark$ \\
\hline Student eligibility & $\checkmark$ & $\checkmark$ & $\checkmark$ & $\checkmark$ \\
\hline Closeness to life & $\checkmark$ & $\checkmark$ & $\checkmark$ & $\checkmark$ \\
\hline
\end{tabular}

The principles of active participation, student eligibility, and closeness to life given in Table 13 are common in all curricula. The openness principle is only included in Singapore SMC. In general, it can be said that the curricula are prepared by paying attention to the teaching principles.

\subsubsection{The technology, tools, and materials used in the teaching process}

The use of technology, tools, and materials used in the teaching process of the curriculum is presented in Table 14 .

Table 14

Technology, Tools, and Materials Used in the Teaching Process

\begin{tabular}{lcccc}
\hline & Turkey & Estonia & Canada & Singapore \\
\hline Videos, graphics, images, etc. & - & - & $\checkmark$ & $\checkmark$ \\
\hline Concept maps & - & - & - & $\checkmark$ \\
\hline Journal Writing & - & - & - & $\checkmark$ \\
\hline Personal blogs & - & - & - & $\checkmark$ \\
\hline Calliper and ruler, protractor & $\checkmark$ & - & - & $\checkmark$ \\
\hline $\begin{array}{l}\text { Computer and communication technology } \\
\text { (ICT) tools }\end{array}$ & $\checkmark$ & $\checkmark$ & $\checkmark$ & $\checkmark$ \\
\hline Calculator & - & $\checkmark$ & $\checkmark$ & $\checkmark$ \\
\hline Mind map & - & - & $\checkmark$ & - \\
\hline
\end{tabular}

As seen in Table 14, the use of ICT tools is included in all curricula. While the mind mapping method is only included in Canadian SMC, concept maps, journal writing, and personal blogs are expressed only in Singapore SMC. While Estonian SMC includes only the use of calculators and ICT tools, Turkish SMC contains the use of callipers, rulers, and ICT. Singapore SMC expresses the use of equipment and materials in more detail than other curricula. Relating to ICT usage, Turkish SMC gives such statements as 'should do/draw through ICT tools, etc.' in the learning outcomes and their descriptions. Estonia, Canada, and Singapore SMCs, mentioning the contribution of the use of ICT to the learning and teaching process, also suggests the use of ICT tools in learning outcomes.

\subsection{Findings on Evaluation of Turkish, Estonian, Canadian, and Singapore Curricula}

The similarities and differences of the curricula were determined by examining the statements related to evaluation in Turkish, Estonian, Canadian, and Singapore secondary mathematics curricula and identifying the types of evaluation and tools used. Estonian and Singapore SMCs 
include some expressions about the types of evaluation while Turkish and Canadian curricula do not include any statements related to evaluation. In Table 15, the types of evaluation, the purposes, and tools of the curricula are shown.

Table 15

Evaluation Types and Tools

\begin{tabular}{|c|c|c|c|}
\hline & & Estonia & Singapore \\
\hline \multirow{3}{*}{$\begin{array}{l}\text { Evaluation Types and } \\
\text { Purposes }\end{array}$} & Formative & $\begin{array}{l}\text { Providing information } \\
\text { on the general problem- } \\
\text { solving, mathematical } \\
\text { reasoning, and attitudes } \\
\text { towards mathematics }\end{array}$ & $\begin{array}{l}\text { Providing students } \\
\text { with timely feedback on } \\
\text { their learning and their } \\
\text { teaching to teachers }\end{array}$ \\
\hline & Summative & $\begin{array}{l}\text { Determining students' } \\
\text { learning with tests, } \\
\text { exams, etc. }\end{array}$ & \\
\hline & Diagnostic & - & $\begin{array}{l}\text { Conducting some form } \\
\text { of diagnostic } \\
\text { assessment to check if } \\
\text { students are ready to } \\
\text { learn }\end{array}$ \\
\hline Evaluation Tools & & $\begin{array}{l}\text { written assignments, } \\
\text { practice activities, oral } \\
\text { answers }\end{array}$ & $\begin{array}{l}\text { Effective inquiry, } \\
\text { performance } \\
\text { evaluation, open-ended } \\
\text { questions, self- } \\
\text { assessment, tests, rubric }\end{array}$ \\
\hline
\end{tabular}

According to Table 15, sample expressions related to the purpose of evaluation types and different tools used are included in the Estonian and Singapore SMCs. While the Singapore SMC points to different methods of evaluation than traditional methods, Estonian SMC includes more classical methods. Although Turkish SMC has no place for the methods and techniques used in the evaluation, it expresses the issues to be considered in making the selection of methods and techniques for evaluation. Canadian SMC does not provide any information on the methods and techniques used in evaluation; also, it contains very little information on assessment.

In general, countries emphasize directly or indirectly the choice of method and technique in their curricula and make the following statements. Turkish SMC draws attention to the use of different evaluation tools and states that only cognitive assessment would not be enough just and that multiple evaluations are the basis. The Singapore SMC, on the other hand, emphasizes that the selected evaluation strategies are purposeful, and recommends teachers discover alternative evaluation strategies and use them in the assessment process. Expressing that alternative evaluation strategies will allow collecting information that cannot be easily reached with traditional evaluation strategies, the curriculum also states that the traditional roles of teachers and students will change. Canadian SMC does not provide any information on this subject.

\subsection{Teacher's Duties and Responsibilities}

When the curricula are examined, it is seen that the teacher is given some duties and responsibilities. When these responsibilities and duties are subjected to content analysis, they are divided into three groups: curriculum-oriented, learning process-oriented, and evaluation-oriented roles and responsibilities. The teacher's responsibilities and duties in relation to the curriculum are summarized in Table 16. 
Table 16

Duties and Responsibilities of Teachers Regarding the Curriculum

\begin{tabular}{lcccc}
\hline Faith in curriculum changes & Turkey & Estonia & Canada & Singapore \\
\hline Understanding the aims of the curriculum & - & - & - & $\checkmark$ \\
\hline $\begin{array}{l}\text { Making decisions about instructions to improve } \\
\text { learning }\end{array}$ & - & - & - & $\checkmark$ \\
\hline $\begin{array}{l}\text { Knowing the necessary information to prepare } \\
\text { the student }\end{array}$ & - & - & - & $\checkmark$ \\
\hline Knowing the evaluation processes & - & - & - & $\checkmark$ \\
\hline Evaluating the curriculum as a whole & - & - & - & $\checkmark$ \\
\hline $\begin{array}{l}\text { Understanding the curriculum and the role of the } \\
\text { links between them }\end{array}$ & - & - & - & $\checkmark$ \\
\hline Knowing what to do at the level of the curriculum & - & - & - & $\checkmark$ \\
\hline
\end{tabular}

When Table 16 is examined, generally, responsibilities regarding the curriculum are included in the Singapore SMC. At the end of each section, the Singapore SMC has a section titled "What does it mean for teachers?". And here, guidance is provided by describing what the teacher should do. The Singapore SMC regards the teacher's beliefs and attitudes as a curriculum implementer to be important and states that the teacher should have sufficient knowledge and equipment to meet the curriculum's aims and objectives. While the Estonian SMC emphasizes the teachers' content choice, the Canadian SMC emphasizes the importance of planning in the teaching and evaluation process in general. The Turkish SMC makes no mention of the teachers' duties and responsibilities in terms of the curriculum. Table 17 explains the teacher's duties and responsibilities towards the learning process.

As can be seen in Table 17, the teacher's duties and responsibilities are discussed in four categories: managing the learning process, guiding and supporting development, using pedagogy and field knowledge, and collaboration. The Singapore SMC is the most detailed description of the teacher's duties and responsibilities. The Singapore SMC outlines the numerous duties and responsibilities that teachers must fulfill during the learning and teaching process. According to Turkish SMC, students' readiness should be considered, and necessary adjustments made to achieve learning outcomes, and teachers should collaborate. The Estonian SMC states that the teacher has an impact on students and learning, while the Canadian SMC states that the teacher should be structured in a meaningful way, that the teacher has an impact on learning, and that the student's readiness should be considered. The teacher's duties and responsibilities regarding the evaluation process are shown in Table 18.

Table 18 divides the teacher's evaluation duties and responsibilities into two categories: monitoring and evaluating students and managing the assessment and evaluation process. While Turkish SMC emphasizes the process's effectiveness and originality, Estonian SMC expresses selfassessment and student support. The preparation of the evaluation plan is mentioned in the Canadian SMC. The Singapore SMC provides a more detailed explanation of the evaluation process, recommending that, unlike in other countries, students be monitored throughout the process, their thinking and understanding evaluated, various assessment strategies researched, and teaching and learning integrated. 


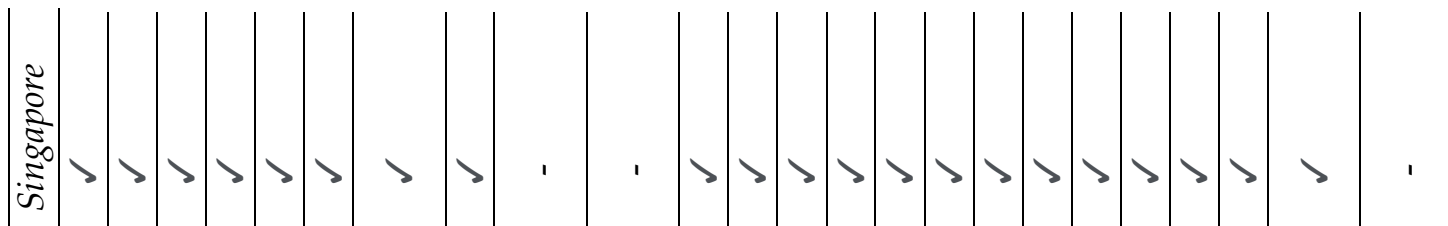

$\frac{0}{3}$

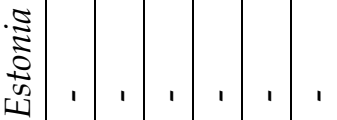

$\frac{\sqrt{3}}{3}$

ڤ్ర

3

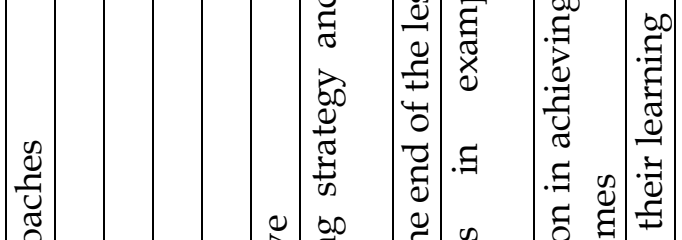

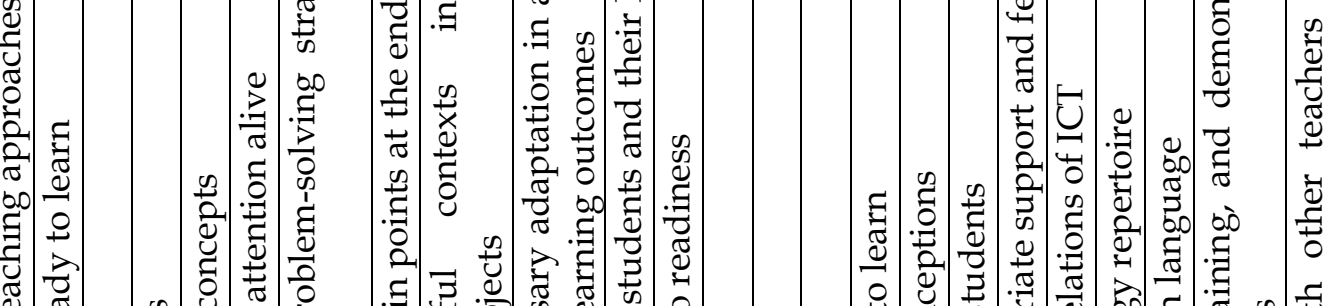

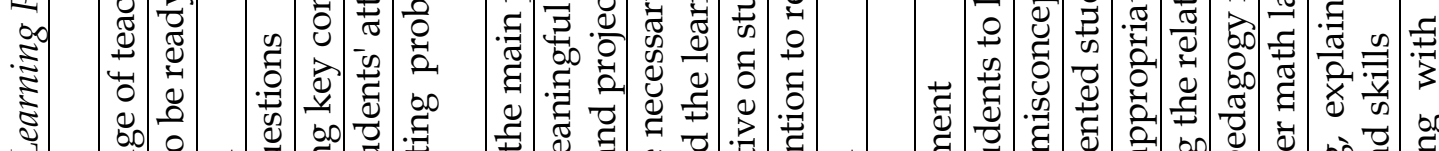

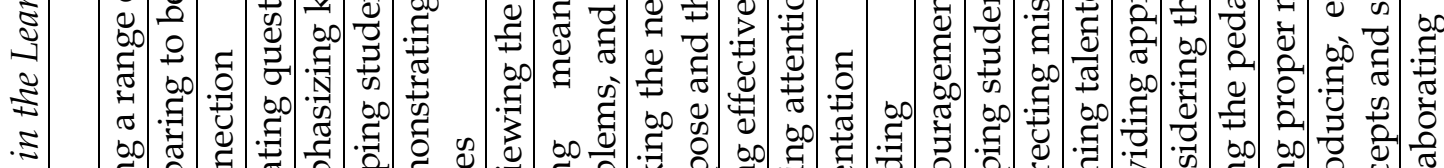

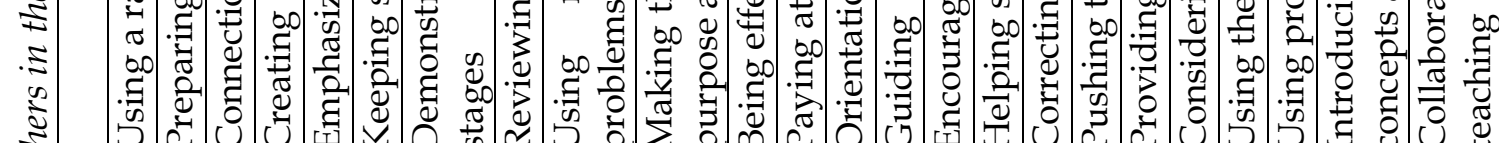

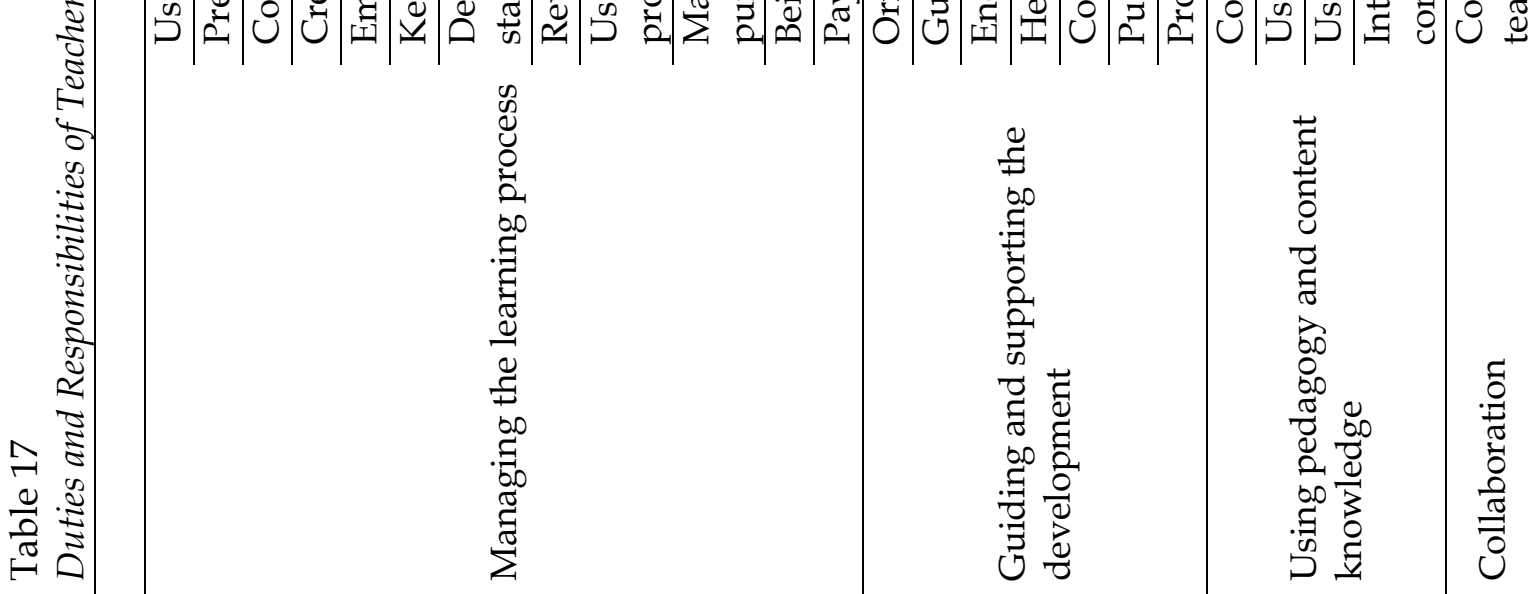


Table 18

Duties and Responsibilities of Teachers in the Evaluation Process

\begin{tabular}{|c|c|c|c|c|c|}
\hline & Duties and responsibilities & Turkey & Estonia & Canada & Singapore \\
\hline \multirow{4}{*}{$\begin{array}{l}\text { Monitoring } \\
\text { and evaluating } \\
\text { students }\end{array}$} & $\begin{array}{l}\text { Monitoring students throughout } \\
\text { the learning process }\end{array}$ & - & - & - & $\checkmark$ \\
\hline & $\begin{array}{l}\text { Evaluating students' thoughts } \\
\text { and their understanding }\end{array}$ & - & - & - & $\checkmark$ \\
\hline & $\begin{array}{l}\text { Helping students do self- } \\
\text { assessment }\end{array}$ & - & $\checkmark$ & - & $\checkmark$ \\
\hline & Supporting students' learning & - & $\checkmark$ & - & $\checkmark$ \\
\hline \multirow{5}{*}{$\begin{array}{l}\text { Managing the } \\
\text { assessment } \\
\text { and evaluation } \\
\text { process }\end{array}$} & $\begin{array}{l}\text { Ensuring the effectiveness of } \\
\text { measurement and evaluation } \\
\text { practices }\end{array}$ & $\checkmark$ & - & - & - \\
\hline & $\begin{array}{l}\text { Being original and creative in } \\
\text { measurement and evaluation } \\
\text { applications }\end{array}$ & $\checkmark$ & - & - & $\checkmark$ \\
\hline & $\begin{array}{l}\text { Researching various evaluation } \\
\text { strategies }\end{array}$ & - & - & - & $\checkmark$ \\
\hline & Preparing the evaluation plan & - & - & $\checkmark$ & - \\
\hline & $\begin{array}{l}\text { Integrating evaluation and } \\
\text { teaching }\end{array}$ & - & - & - & $\checkmark$ \\
\hline
\end{tabular}

\section{Discussion and Conclusion}

The similarities and differences of Turkish, Estonian, Canadian, and Singapore Secondary Mathematics Curricula in terms of general features, goals, learning objectives/outcomes, content, teaching-learning process, and teacher responsibility in the implementation of the curriculum were aimed to be discovered through detailed analyses. Considering the date of entry into force of the curriculum in terms of general features, the same curricula have been used in Turkey since 2018, in Estonia since 2011, in Canada since 2008 and in Singapore since 2012. Singapore SMC states that it will be updated regularly on certain dates and that there will not be much change in the contentrelated part but there may only be revisions regarding teaching methods (Ministry of Education Singapore, 2012). Estonia and Canada, on the other hand, have been using the same curricula and updating them since their entry into force. In the last decade, Turkey has changed its program three times. The subjects have been simplified in terms of content as a result of the changes. The separation of mathematics into advanced and basic levels was welcomed when the program was published in 2013, but the removal of activity examples and suggestions in the program has been criticized, leading to the program becoming nothing more than a list of objectives and topics (Yazıcilar \& Bümen, 2017).

Curricula aim to educate people not only cognitively but also affectively. Curricula are designed to educate people in both cognitive and affective ways. For this reason, in addition to cognitive elements, affective elements should be included when developing curricula. There are many sub-dimensions to affective elements, and some of them are intended to express values in education (Aşıcı \& Dede, 2019). Integrating values education into the curriculum will make it easier to teach values in the activities that need to be done and will allow students to absorb these values (Aktepe \& Tahirolu, 2016). Teachers should structure the values specified in the curriculum and transfer them according to the interests and expectations of the students (Aktan \& Kılıç, 2015). In Turkish and Estonian curricula, there are statements about values, and different values are included in the curricula. However, there is no information on how the curriculum values can be gained in the learning-teaching process, and it is clear that they are unrelated to learning outcomes. There is no expression of value in Canadian and Singapore SMCs. 
Turkey Higher Education Qualifications Framework, associated with European Qualifications Framework, has been prepared in order to be implemented in curricula and the competence has been defined as "the ability to use knowledge, personal, social and/or methodological skills at work, study environments and in professional and personal development" (The Council of Higher Education, 2011). Competence can also be expressed as having the necessary equipment to do a job. When the key competencies given in Turkish SMC are examined, it is seen that the statements are general and are not associated with learning outcomes. Estonian SMC is expected to have more visible effects in the teaching process, as it expresses the competencies it defines by associating them with mathematics.

The mathematics discipline has a variety of characteristics and process skills due to its unique nature. Singapore and Canada have included and made the necessary explanations about the SMC process skills and features. Turkey and Estonia SMCs have not provided any information on their mathematical processing skills and features. This situation may make it difficult for teachers to make the necessary connections in the learning-teaching process.

When the most frequently used expressions are examined, it is seen that the expression 'problem' is the most frequently used expression in all curricula. When the frequently used expressions are examined, it can be said that the curricula are consistent with their goals. Singapore, for example, prioritized problem-solving in its curriculum and designed its entire curriculum around it. The curriculum, which aims to provide individuals with 21st-century skills through problem-solving, evokes this in its general structure (Ministry of Education of Singapore, 2012) and, therefore, this has been the most commonly used word in the curriculum. Canadian $\mathrm{SMC}$, on the other hand, has organized a curriculum that aims to teach meaningful learning by putting the student in the center (Alberta Education, 2008) so the frequent use of the word "student" is parallel to this. In Estonian SMC, it is observed that there is an attempt to associate mathematics with life and that the frequent use of the word mathematics is compatible with this situation. In Turkey, frequently used words are associated with more gain and subject content, but no meaningful link to the curriculum's overall structure has been established. The reason for this could be that the curriculum's explanations do not focus solely on mathematics, but also include general statements.

When the goals of the countries' mathematics curricula are examined using Posner and Rudnitsky's classification, it is clear that they have the most goals in the cognitive domain, the least in the affective domain, and no goals in the psychomotor domain. Likewise, when the learning outcomes are examined, all of them in the curriculum belonging the cognitive domain, and no learning outcomes in the affective or psychomotor domain have been found. It can be said that this creates a deficiency in terms of curriculum. It is important to include other domains besides the cognitive domain both in goals and in learning outcomes to have a quality mathematics education. Even though the mathematics lesson is thought to be composed of cognitive processes by its nature, it is necessary to act holistically while determining the goals of the lesson (Ernest, 2010; Ersoy, 2006). Considering that individuals acquire different affective outcomes in the process such as perseverance and taking responsibility, in addition, to learn mathematics cognitively (Aşıcı \& Dede, 2019), affective outcomes should be included more in the curriculum and psychomotor outcomes should be included in the goals as much as the lesson allows.

When learning outcomes are classified according to TIMSS cognitive domain, it is seen that in Turkish and Estonian SMCs, the outcomes are mainly at the knowing level and there are very few outcomes at the reasoning level. Canadian SMC focuses on applying and reasoning domains and includes very few outcomes in the knowing domain while Singapore SMC focuses on knowing, applying, and reasoning domains equally. According to this situation, this is a meaningful finding for Canada and Singapore, who succeed in international exams, and it is remarkable for Estonia. Different information about the Estonian education system is also needed to explain its international success. Considering the unique structure of the Estonian education system, such factors as the provision of education by the state with equal opportunities, the autonomy of 
principals and teachers in schools (Lees, 2016; Reiska, nd.), the emphasis on proofing and problemsolving in mathematics education from primary school to high school (Hemmi et al., 2013) may have brought success in education. The reason why Turkey performs insufficiently compared to other countries may be the fact that it has a small number of learning outcomes in the reasoning domain. It has been concluded that there are considerably more learning outcomes and limited duration for them in Turkey's mathematics curriculum compared to other countries according to other studies (Duygu, 2013; Galo, 2008; Tezcan, 2016).

When the curricula are examined, the learning areas and subjects are given separately in Turkish and Singapore SMCs. While Estonian SMC includes only the titles that it calls them as the subject area, Canadian SMC only includes the topics. When they are analyzed according to the subjects, it is seen that the content of the curricula is not very different but Turkish SMC is more intense compared to others. Unlike Turkish SMC, Singapore SMC aims to teach more deeply with a narrower content through its motto "teach less, learn more!" (Tee Ng, 2008). While Canadian and Singapore curricula include basic topics such as equations and inequalities, functions, and trigonometry, they do not include advanced subjects like limit, derivative, and integral. These subjects are taught optionally in advanced or post-secondary curricula in Canada and Singapore.

According to the content analysis of the learning-teaching process, the curriculum that gives the most detailed information about the approach, method, and technique used is Singapore SMC. Project implementation, demonstration, observation, models, and applications related to teaching methods and techniques are common in all curricula. Studies have shown that the use of different approaches, methods, and techniques in the learning-teaching and evaluation enriches teaching and positively affects learning (Erbilge 2019; Kaytan, 2009; Khan et al., 2018). When teaching principles are examined, it is observed that some principles are stated explicitly and some are implicit. The principles of goal-oriented, active participation, student eligibility, and closeness to life are expressed in common in all curricula. The use of ICT tools in technology, equipment, and materials are included in all curricula. Turkish SMC provides information related to the approaches, methods, and techniques used but does not mention where and how they can be used. In a sense, although it is thought that it gives the teacher flexibility in this subject, it has been stated in the studies that the teachers feel incomplete and want to receive in-service training on the learning-teaching process (Biçer \& Ada, 2020). It has been understood that teachers could not benefit from this, especially regarding information and communication technologies (Çiftçi \& Tatar, 2015). How the ICT can be utilized is not defined sufficiently in the curriculum and it is pretty intense in terms of the content may be the results of this situation (Aydın et al., 2018; Çiftçi \& Tatar, 2015; Yazıcılar \& Bümen, 2017).

Evaluation is carried out not only for assessing student learning but also for various purposes. The three most important of these purposes are to recognize the student, monitor their learning, and determine their learning levels. The type of evaluation chosen for the purpose will facilitate getting correct results by ensuring that the evaluation achieves its purpose (Acar, 2019; Özçelik, 2014). Statements on the types of evaluation are included in Estonian and Singapore SMCs. There are no statements related to the types of evaluation in Turkish and Canadian SMCs. It is seen that Estonian and Singapore SMCs express a few different types of purposes in the evaluation, not all of them. The curricula, which also indicate the usage purposes of the evaluation types, guide the teachers who are the implementers of the curriculum with these explanations. Evaluation methods and techniques play an important role in a well-planned teaching process. As the type of evaluation, which is used to assess success at the end of the teaching process or to determine students' readiness may differ, the methods and techniques should be defined according to this and they should serve the purpose (Acar, 2019). For the evaluation to be effective and to reveal the student's weaknesses and strengths fully, many different methods and techniques should be used instead of traditional exams limited in time (National Council of Teachers of Mathematics, 1995). Providing information about the tools that can be used in evaluating Estonian and Singapore SMCs state different tools. While Estonian SMC refers to more traditional tools, Singapore SMC 
includes non-traditional alternative tools. The demand for using alternative approaches is important in terms of showing that a more comprehensive and more detailed evaluation is desired. The points to be considered in evaluation are expressed differently by each curriculum and the commonly stated expression is 'evaluation which is a part of the learning process and should be done continuously'. It has been concluded that in line with previous researches, there is not sufficient information on the evaluation and assessment process in Turkish SMC (Biçer \& Ada, 2020; Çiftçi et al., 2013). Adding methods related to evaluation and assessment to the curriculum will make mathematics education more efficient as it will guide teachers better.

The teacher has duties and responsibilities towards the curriculum and the learning-teaching process as he/she teaches learning in a student-centered approach, educates himself/herself in a way that can provide the needs of the student, follows technology, and reflects this in his/her lessons (Uysal, 2017). In addition, he/she has duties and responsibilities for the evaluation process, such as determining methods and techniques for evaluation and assessment, using different evaluation tools, interpreting the evaluation results correctly, and giving feedback about the student's development and learning (Çermik \& Turan Gülaç, 2014). When the curricula are examined, Singapore SMC systematically guides the teacher by expressing what the teacher should do. Also, the Singapore SMC regarding the teacher's beliefs and attitudes as the implementer of the curriculum as important states that the teacher should have sufficient knowledge and equipment to fulfill the goals and objectives of the curriculum. It can be said in general that Turkish, Estonian, and Canadian curricula do not sufficiently include the duties and responsibilities of the teacher. Studies have shown that teachers generally tend to continue the order they are accustomed to (Biçer \& Ada, 2020; Ekşioğlu, 2013). Therefore, by clearly expressing the teacher's duties and responsibilities in the curriculum, more comprehensive information can be given about the curriculum, the learning-teaching process, and evaluation, and it can be ensured that teachers become more aware of the curriculum and make more accurate applications.

This research, which allows for an examination of the Mathematics curricula of countries that have performed well in international exams, can provide recommendations and contribute to the field's curriculum development. Although there are similarities and differences in various dimensions of curricula based on country characteristics, it is widely recognized that curricula are the source of a country's success. The textbooks of these countries, learning-teaching processes, and teacher competencies can all be included in the study, as the educational process is not limited to the curriculum dimension.

Acknowledgements. This research is a part of the Master's thesis of the first author under the supervision of the second author.

\section{References}

Acar, F. (2019). Öğrenmede başarı ve sınıf içi öğrenmelerin değerlendirilmesi [Evaluation of learning success and classroom learning]. T. Duman \&, D. Peker Ünal (Eds.), Öğretim ilke ve yöntemleri [Teaching principles and methods] (pp. 318-343). Pegem Akademi Publishing.

Aktan O., \& Kılıç A.(2015). The case of supporting the values in social sciences education program with the values which are in 100 basic works. Journal of Values Education, 13(30), 7-68.

Aktepe, V., \& Tahiroğlu, M (2016). Values education approaches and sample activities. International Journal of Social Science, 42(3), 361-384. http:/ / dx.doi.org/10.9761/JASSS2941

Alberta Education. (2008). Mathematics (10-12). https://education.alberta.ca/mathematics-10-12/programsof-study/everyone/programs-of-study/

Aşıc1, F., \& Dede, Y. (2019). The transmission of educational values through mathematical problems: A theoretical study. Necatibey Faculty of Education Electronic Journal of Science and Mathematics Education, 13(1), 260-283.

Aydın, M., Laçin, S., \& Keskin, İ. (2018). Teacher opinions on the implementation of the secondary school mathematics curriculum. International e-Journal of Educational Studies, 2(3), 1-11. https://doi.org/10.31458/iejes.413967 
Balc1, A. (2013). Sosyal bilimlerde araştırma yöntem, teknik ve ilkeler [Research methods, techniques and principles in social sciences]. Pegem Akademi Publishing.

Işık, A., Çiltaş, A., \& Bekdemir, M. (2008). The importance and necessity of mathematics education. Journal of Kazım Karabekir Education Faculty, 0(17), 174-184.

Biçer, F., \& Ada, T. (2020). Opinions of vocational high school math teachers on the mathematics course curriculum. Anadolu Journal of Educational Sciences International, 10(1), 543-582. https://doi.org/10.18039/ajesi.682059

Cambridge International (2019, August). International surveys TIMSS, PISA, PIRLS. https:/ / www.cambridgeinternational.org/Images/271193-international-surveys-pisa-timss-pirls.pdf

Creswell, J. W., \& Plano Clark, V. L. (2011). Designing and Conducting Mixed Methods Research (2th Ed). Sage Publications.

Çermik, H., \& Turan Güllaç, E. (2014). Öğretmen nitelikleri ve yeterlikleri [Teacher qualifications and competencies]. In Şeref Tan (Ed.). Öğretim ilke ve yöntemleri [Teaching principles and methods] (pp. 483516). Pegem Akademi Publishing.

Çiftçi, O., \& Tatar, E. (2015). Teachers' opinions about the updated secondary mathematics curriculum. Turkish Journal of Computer and Mathematics Education, 6(2), 285298. https://doi.org/10.16949/turcomat.15375

Çiftçi, Z. B., Akgün, L., \& Deniz, D. (2013). Teachers' opinions and solution suggestions regarding encountered issues on the ninth grade mathematics curriculum. Anadolu Journal of Educational Sciences International, 3(1), 1-21.

Çubukcu, Z., İnci T., \& Yılmaz B.Y. (2016). Determination of comparative curriculum research trends- a content analysis. International Journal of Turkish Literature Culture Education, 5(1), 446-468.

Demirel, Ö. (2019). Eğitimde program geliştirme kuramdan uygulamaya [Curriculum development in education from theory to practice]. Pegem Akademi Publishing.

Duygu, N. (2013). International comparative study of elementary school mathematics curriculum [Unpublished master's thesis]. Gaziosmanpaşa University, Tokat, Turkey.

Ekşioğlu, S. (2013). Evaluation of modular education program implementation in vocational and technical high schools [Unpublished doctoral dissertation]. Gazi University, Ankara, Turkey.

Erbilge, A. E. (2019). Comparison of secondary school mathematics curriculum of Turkey, Canada, and Hong Kong [Unpublished master's thesis]. Marmara University, Istanbul, Turkey.

Ergün, M. (1985). Karşılaştırmalı eğitim [Comparative education]. http://mustafaergun.com.tr/wordpress/wpcontent/uploads/2015/11/kegitim.pdf

Ernest, P. (2010). The social outcomes of learning mathematics: Standard, unintended or visionary?. International Journal of Education in Mathematics, Science and Technology, 3(3), 187-192.

Ersoy, Y. (2003). Teknoloji destekli matematik öğretimi-II: hesap makinesinin matematik etkinliklerinde kullanilması [Technology supported mathematics teaching-II: using calculator in mathematics activities]. Elementary Education Online, 2(2), 35-60.

Ersoy, Y. (2006). Innovations in mathematics curricula of elementary schools-I: Objective, content and acquisition. Elementary Education Online, 5(1), 30-44.

Ersoy, Y. (2010). Uluslararası öğrenci değerlendirme programı (PISA, 2016)-1: Türkiye'de öğrencilerin fen okuryazarliğı [Program for International Student Assessment (PISA 2016) -1: scientific literacy of students in Turkey]. http://www.f2e2-ogretmen.com/dagarcigimiz/f2e2-40.pdf

Galo, E. (2008). A Comparative Analysis of the mathematics curricula for primary schools in Turkey and Kosova [Unpublished MA thesis]. Marmara University, İstanbul, Turkey.

Guba, E. G., \& Lincoln, Y. S. (1982). Epistemological and methodological bases of naturalistic inquiry. Educational Communication and Technology Journal, 30(4), 233-252.

Guba, E. G., \& Lincoln, Y. S. (1985). Naturalistic inquiry. Sage Publications.

Güner, H., Çelebi, N., Taşçı Kaya, G., \& Korumaz, M. (2014). Analysis of International Tests (PISA, TIMSS, and PIRLS) in the Context of Neoliberal Education Policies and Equality of Opportunity in Education. Journal of History Culture and Art Research, 3(3), 33-75.

Hemmi, K., Lepik, M., \& Viholainen, A. (2013). Analyzing proof-related competencies in Estonian, Finnish and Swedish mathematics curricula - towards a framework of developmental proof. Journal of Curriculum Studies, 45(3), 354-378. https:// doi.org/10.1080/00220272.2012.754055

Kaytan, E. (2009). Comparison of primary mathematics curriculum of Turkey, Singapore, and England [Unpublished master's thesis]. Hacettepe University, Ankara, Turkey. 
Khan, H. M. A., Farooqi, M. T. K., \& Mehmood, S. (2018). Curriculum of mathematics in Pakistan and international standards: A comparative study. Global Social Sciences Review, 3(2), 273-300.

Lees, M. (2016, August). Estonian Education System 1990-2016- reforms and their impact. http:/ / 4liberty.eu/estonian-education-system-1990-2016-reforms-and-their-impact/

Matthews, B., \& Ross, L. (2010). Research methods: A practical guide for the social sciences Pearson Education.

Miles, M. B. \& Huberman, A. M. (2016). Nitel Veri Analizi [Qualitative Data Analysis] (Trans. S. Akbaba Altun \& A. Ersoy). Pegem Akademi Publishing.

Ministry of National Education (Turkey). (2018). Illköğretim matematik öğretim programı [Secondary school mathematics curriculum]. http://mufredat.meb.gov.tr/Dosyalar/201821102727101OGM\%20MATEMAT\%C4\%B0K\%20PRG\%2020.01.2018.pdf

Ministry of Education Singapore. (2012). Mathematics syllabus secondary one to four express course normal (Academic) course. http://m.aeis.org.cn/ueditor/

Mullis, I.V.S., \& Martin, M.O. (2017). TIMSS 2019 assessment frameworks. https:/ / timssandpirls.bc.edu/timss2019/frameworks/

Mullis, I.V.S., Martin, M.O., Foy, P., \& Arora, A. (2012). TIMSS 2011 international results in mathematics. TIMSS \& PIRLS International Study Center.. https://timssandpirls.bc.edu/timss2011/international-resultsmathematics.html

Mullis, I. V. S., Martin, M. O., Foy, P., \& Hooper, M. (2016). TIMSS 2015 international results in mathematics. TIMSS \& PIRLS International Study Center. http://timssandpirls.bc.edu/timss2015/internationalresults/

National Council of Teachers of Mathematics. (1995). Assessment standards for school mathematics. Author.

Organisation for Economic Co-operation and Development [OECD] (2010). PISA 2009 Results: What students know and can do: Student performance in reading, mathematics, and science (Volume I). Author. http://dx.doi.org/10.1787/9789264091450-en

Organisation for Economic Co-operation and Development [OECD] (2014). PISA 2012 results: what students know and can do: Student performance in mathematics, reading and science (Volume I). Author. https://www.oecd.org/pisa/keyfindings/pisa-2012-results-volume-I.pdf

Organisation for Economic Co-operation and Development [OECD] (2018). PISA 2015 results in focus. Author. https://www.oecd.org/pisa/pisa-2015-results-in-focus.pdf

Organisation for Economic Co-operation and Development [OECD] (2019). PISA 2018 results (Volume I): What students know and can do, PISA. Author. https:// doi.org/10.1787/5f07c754-en

Özçelik, D. A. (2014). Ĕ̆itim programları ve öğretimi [Education programs and teaching]. Pegem Akademi Publishing.

Posner G. J., \& Rudnitsky, A. N. (2006). Course design: A guide to curriculum development for teachers. Pearson Education.

Reiska, P. (n.d.). Estonian success in PISA - what are the reasons behind that?. Tallin University. https://www.hm.ee/sites/default/files/henno_presentation_final_pisa_191114.pdf

Republic of Estonia Ministry of Education and Research. (2004). Appendix 3 of regulation no2 of the government of the republic of 6 January 2011 national curriculum for upper secondary schools. https://www.hm.ee/sites/default/files/est_upper_secondary_nat_cur_2014_appendix_3_final.pdf

Seah, W. T., \& Bishop, A. (2014). Realizing a mathematics education for nation-building in Southeast Asia in the new millennium [CD-ROM]. In S. P. Loo (Ed.), Proceedings of the MERA-ERA Joint Conference (Vol. 3, pp. 1241-1249). Malaysian Educational Research Association and Educational Research Association Singapore.

Tee Ng, P. (2008). Educational reform in Singapore: from quantity to quality. Educational Research for Policy and Practice, 7, 5-15. https://doi.org/10.1007/s10671-007-9042-x

Tezcan, S. (2016). A comparison of 5-8. grade school mathematics curriculum from Turkey, Singapore, and the United States of America (the case of Wisconsin) [Unpublished MA thesis]. Gaziantep University, Gaziantep, Turkey.

The Council of Higher Education (2011). Turkey Higher Education Qualifications Framework. http://tyyc.yok.gov.tr/dosyalar/21122011-TYYC\%20Yonetmeligi-Taslak.doc

TIMMS (2019). TIMMS 2019 Encyclopedia: Education policy and curriculum in Mathematics and Science. https://timssandpirls.bc.edu/timss2019/encyclopedia/turkey.html

Usta, H.G. (2014). An international comparison PISA 2003 and 2012 according to mathematical literacy Turkey and Finland [Unpublished doctoral dissertation]. Ankara University, Ankara, Turkey. 
Uysal, R. (2017). Analysis of middle school mathematics teaching programs implemented between 1998-2013 [Unpublished master's thesis]. Kastamonu University, Kastamonu, Turkey.

Walliman, N. (2015). Social research methods: The essentials. Sage.

Yazıcılar, Ü., \& Bümen, N. T. (2017). 2005, 2011 ve 2013 yıllarında uygulamaya konulan lise matematik dersi öğretim programları üzerine bir analiz [An analysis on the high school mathematics curriculum put into practice in 2005, 2011, and 2013]. In Ö. Demirel \& S. Dinçer (Eds.) Küreselleşen Dünyada Eğitim [Education in a Globalizing World] (pp.139-166). Pegem Akademi Publishing.

Yıldırım, C., \& Türkoğlu, A. (2018). Reflections of comparative education: "Ten years later". Adnan Menderes University, Journal of Institute of Social Sciences, 5(1), 31-45. 